\title{
PENDAPATAN PEDAGANG PADA MASA PANDEMI COVID- 19 DI PASAR TANAWANGKO DESA BORGO KABUPATEN MINAHASA
}

\author{
MERCHANT'S REVENUE IN COVID-19 PANDEMIC TIME IN TANAWANGKO MARKET, \\ BORGO VILLAGE, MINAHASA DISTRICT
}

$\underline{\text { Rivaldy Angelo Karundeng }}^{(1)}$, Theodora Maulina Katiandagho ${ }^{(2)}$, Gene Henfried Meyer Kapantow ${ }^{(2)}$

1) Mahasiswa Program Studi Agribisnis, Fakultas Pertanian, Universitas Sam Ratulangi, Manado

2) Dosen Program Studi Agribisnis, Fakultas Pertanian, Universitas Sam Ratulangi, Manado

*Penulis untuk korespondensi: karundengansow23@gmail.com

Naskah diterima melalui Website Jurnal Ilmiah agrisosioekonomi@unsrat.ac.id

Sabtu, 17 April 2021

Disetujui diterbitkan

Jumat, 28 Mei 2021

\begin{abstract}
This study aims to determine the income of horticultural merchants in Tanawangko Market, Borgo Village, Tombariri District, Minahasa Regency during the Covid-19 pandemic. This research was conducted for two months, namely in October and November 2020. The data used in this study are primary data and secondary data obtained from the survey method. Primary data were obtained through interviews with 20 people based on a list of questions that had been prepared, Secondary data is obtained from the districts offices, village offices, and related agencies. The data analysis used in this research is descriptive analysis which is presented in table form. The results of this study indicate that during this pandemic the Tanawangko Market merchants had an average income of IDR 812,300 / week.
\end{abstract}

Keywords : revenue; merchant; market; Covid-19

\begin{abstract}
ABSTRAK
Penelitian ini bertujuan untuk mengetahui pendapatan pedagang hortikultura di Pasar Tanawangko, Desa Borgo, Kecamatan Tombariri Kabupaten Minahasa pada masa pandemi Covid19. Penelitian ini dilaksanakan selama dua bulan yaitu pada bulan Oktober dan November tahun 2020. Data yang digunakan dalam penelitian ini adalah data primer dan data sekunder yang diperoleh dari metode survei. Data primer diperoleh melalui wawancara pada 20 orang berdasarkan daftar pertanyaan yang telah disiapkan, sedangkan data sekunder diperoleh dari kantor kecamatan, kantor desa, serta instansi yang terkait. Analisis data yang digunakan dalam penelitian ini adalah analisis deskriptif yang disajikan dalam bentuk tabel. Hasil penelitian ini menunjukkan bahwa di masa pandemi ini pedagang Pasar Tanawangko memiliki pendapatan rata-rata Rp. 812,300/Minggu.
\end{abstract}

Kata Kunci : pendapatan; pedagang; pasar; Covid-19 


\section{PENDAHULUAN}

\section{Latar Belakang \\ Virus Corona penyebab Covid-19} merupakan salah satu virus saat ini menyebar di seluruh dunia. Virus ini menyebar pada manusia melalui cairan yang sangat kecil dan jika masuk dalam tubuh manusia akan berkembang biak dan menyerang bagian dalam tubuh terutama bagian pernapasan. Protokol pencegahan penyebaran virus ini agar tidak mudah terjangkit dengan cara memakai masker, mencuci tangan, menjaga jarak, tidak melakukan kegiatan yang tidak penting diluar rumah ataupun pertemuan dengan banyak orang. Dampak diberlakukannya PSBB (Pembatasan Sosial Berskala Besar) menyebabkan terjadinya berkurangnya aktivitas.

Penyebaran pandemi Covid-19 di Indonesia memberikan dampak yang sangat terasa oleh masyarakat Indonesia, khususnya dalam kegiatan pasar tradisional. Pasar merupakan dimana terjadi transaksi antara penjual dan pembeli, barang yang ditransaksikan bisa berupa barang apapun, mulai dari beras, sayur- mayur, jasa angkutan, uang dan tenaga kerja (Boediono, 2000). akan tetapi saat masa pandemi semua aktivitas tersebut sangat berkurang dilihat dari kios atau lapak di pasar tidak berjualan dikarenakan berkurangnya aktivitas. Terlebih pedagang sayur-mayur karena permasalahan utama pada produk hortikultura adalah 1. mudah busuk (bulkiness), 2. banyak menggunakan tempat (volumness), 3. tingkat penyusutan yang lebih tinggi, 4. mudah rusak, 5. sangat tergantung dengan musim, maka penjualan terhadap komoditas hortikultura harus secepatnya dilakukan (as soon as possible doing) agar pedagang tidak mengalami kerugian.

Pasar Tanawangko merupakan satu satunya pasar tradisional yang berada di Kecamatan Tombariri Kabupaten Minahasa Desa Borgo, sehingga masyarakat sangat bergantung pada pasar tersebut dalam memenuhi kebutuhan sehari - hari, pasar Tanawangko memiliki jadwal pasar besar pada hari senin dan kamis dan buka setiap hari untuk penjualan bahan pokok. Pasar Tanawangko memiliki 174 lapak, 27 kios dengan total 76 pedagang, terdapat 40 pedagang hortikultura. Bagi para pedagang hortikultura di pasar tradisional Tanawangko tentunya sangat merasakan dampak pada penjualan, di masa pandemi Covid-19. Berdasarkan latar belakang di atas penulis tertarik untuk mengetahui pendapatan pedagang hortikultura pada masa pandemi di pasar Tanawangko, Desa Borgo Kecamatan Tombariri Kab. Minahasa.

\section{Pasar}

Pasar merupakan seperangkat pembeli aktual dan potensial dari sebuah produk atau jasa. Ukuran dari pasar sendiri tergantung pada jumlah orang yang menunjukan kebutuhan, memiliki kemampuan dalam pertukaran. Banyak pemasar memandang penjual sebagai industri dan pembeli sebagai pasar, dimana penjual mengirimkan produk dan jasa yang mereka produksi dan mengkomunikasikan atau menyampaikannya kepada pasar; sebagai gantinya, mereka akan menerima uang dan informasi dari pasar (Kotler dan Amstrong, 1999). Pasar adalah sekumpulan orang yang memiliki keinginan untuk puas, uang yang digunakan untuk berbelanja, serta memiliki kemauan untuk membelanjakan uang tersebut (Stanton, 1993).

\section{Hortikultura}

Hortikultura merupakan budidaya tanaman sayuran, buah-buahan, dan berbagai tanaman hias, hortikultura saat ini menjadi komoditas yang menguntungkan karena pertumbuhan ekonomi yang semakin meningkat maka pendapatan masyarakat yang juga meningkat. Peningkatan konsumsi hortikultura disebabkan karena struktur konsumsi bahan pangan cenderung bergeser pada bahan non pangan. Konsumsi masyarakat sekarang ini memiliki kecenderungan menghindari bahan pangan dengan kolestrol tinggi seperti produk pangan asal ternak. Hortikultura juga berperan sebagai sumber gizi masyarakat, penyedia lapangan pekerjaan, dan penunjang kegiatan agrowisata dan agroindustri. Hal ini menunjukkan bahwa pengembangan hortikultura terkait dengan aspek yang lebih luas yang meliputi tekno-ekonomi dengan sosio-budaya petani. Ditinjau dari proses waktu produksi, musim tanam yang pendek memungkinkan perputaran modal semakin cepat dan dapat meminimalkan ketidakpastian karena faktor alam (Mubyarto, 1995). 


\section{Pandemi Covid-19}

Pandemi adalah suatu wabah penyakit global. Menurut World Health Organization (WHO), pandemi dinyatakan ketika penyakit baru menyebar di seluruh dunia melampaui batas. Ada banyak contoh dalam sejarah, yang terbaru ada pandemi Covid-19. Pandemi yang mirip flu ini dinyatakan oleh WHO pada 12 Maret 2020. Istilah pandemi menurut KBBI dimaknai sebagai wabah yang berjangkit serempak di mana-mana meliputi daerah geografi yang luas. Dalam pengertian yang paling klasik, ketika sebuah epidemi menyebar ke beberapa negara atau wilayah dunia. Wabah penyakit yang masuk dalam kategori pandemi adalah penyakit menular dan memiliki garis infeksi berkelanjutan. Maka, jika ada kasus terjadi di beberapa negara lainnya selain negara asal, akan tetap digolongkan sebagai pandemi.

Covid-19 dimulai sebagai epidemi di China sebelum menyebar ke seluruh dunia dalam hitungan bulan dan menjadi pandemi. Meski demikian, epidemi tidak selalu menjadi pandemi dan tidak selalu memiliki transisi yang cepat atau jelas.

Penyakit dikategorikan sebagai pandemi apabila penyakit itu berkembang di beberapa wilayah yang baru terdampak melalui penularan setempat. Statusvirus corona yang telah berubah menjadi pandemi, bukan berarti virus ini semakin liar dan kuat, melainkan penyebaran virus corona yang semakin meluas dan menyebar di berbagai wilayah dunia. Dengan naiknya status corona menjadi pandemi, WHO berharap negara-negara di dunia bisa melakukan penanganan ekstra.

\section{Pendapatan}

Soekartawi (1995) menyatakan pendapatan usahatani adalah selisih antara penerimaan (TR) dan semua biaya (TC), dimana penerimaan usahatani adalah perkalian antara produksi dan harga jual, sedangkan biaya adalah semua pengeluaran yang digunakan dalam suatu usahatani. Jadi rumus pendapatan dapat dituliskan sebagai berikut:

$$
\pi=\mathbf{T R}-\mathbf{T C}
$$

Keterangan:

$\pi=$ Pendapatan

$\mathrm{TR}=$ Total Revenue (Total Penerimaan) $\mathrm{TC}=$ Total Cost (Total Biaya)

Dimana: $\mathrm{TR}=\mathrm{P} . \mathrm{Q} \mathrm{TC}=\mathrm{FC}+\mathrm{VC}$

Dengan demikian pendapatan penjual diperoleh dari seberapa banyak jumlah barang yang terjual dengan harga yang telah disepakati antara penjual dan pembeli. Berdasarkan uraian di atas maka dapat disimpulkan bahwa pendapatan pedagang pasar adalah pendapatan yang diterima atas jumlah barang yang terjual dikalikan dengan harga per unit barang tersebut menurut jenis-jenis dagangannya.

\section{Rumusan Masalah}

Berdasarkan latar belakang yang telah di kemukakan maka yang menjadi permasalahan dalam penelitian adalah Berapa pendapatan pedagang di pasar Tanawangko pada masa pandemi?

\section{Tujuan Penelitian}

Berdasarkan latar belakang dan perumusan masalah, maka penelitian ini bertujuan untuk mengetahui pendapatan pedagang di pasar Tanawangko pada masa pandemi.

\section{Manfaat Penelitian}

Memberikan informasi dan masukan kepada pedagang dalam mengembangkan/menghadapi masa pandemi serta dapat dijadikan referensi untuk penelitian-penelitian yang terkait dampak pandemi.

\section{METODE PENELITIAN}

\section{Waktu dan Tempat Penelitian}

Penelitian ini di laksanakan selama dua bulan yaitu pada bulan Oktober dan November tahun 2020 mulai dari persiapan sampai penyusunan laporan penelitian. Tempat penelitian adalah Pasar Tanawangko Desa Borgo Kecamatan Tombariri Kabupaten Minahasa. 


\section{Metode Pengumpulan Data}

Metode yang digunakan dalam penelitian ini adalah metode survei dengan cara mengambil data primer dan data sekunder. Data primer diperoleh melalui daftar pertanyaan yang telah disiapkan, sedangkan data sekunder diperoleh dari kantor kecamatan, kantor desa, serta instansi yang terkait.

\section{Metode Pengambilan Sampel}

Untuk pengambilan sampel menggunakan metode purposive sampling yaitu pengambilan data atau responden dilakukan secara sengaja dengan mempertimbangkan kriteria responden yang menjadi sampel adalah pedagang hortikultura di pasar tanawangko. Dalam penelitian ini banyaknya sampel yang diambil adalah seluruh pedagang hortikultura, yakni sebanyak 20 orang.

\section{Konsep Pengukuran Variabel}

Adapun variabel yang di teliti adalah:

1. Karateristik Responden:

a. Umur pedagang (Tahun).

b. Tingkat pendidikan (SD, SMP, SMA, PT).

c. Jumlah tanggungan anggota keluarga (orang).

2. Jumlah penjualan per hari.

3. Harga beli dan harga barang dagangan (Rp).

4. Penerimaan yaitu perkalian antara jumlah dagangan dengan harga jual (Rp).

5. Pengeluaran usaha.

6. Pendapatan yaitu penerimaan dikurangi total biaya.

Metode Analisis Data Analisis data yang digunakan dalam penelitian ini adalah analisis deskriptif yang disajikan dalam bentuk tabel. Sedangkan pendapatan pedagang diperoleh dengan rumus:

$$
\begin{aligned}
& \boldsymbol{\pi}=\mathbf{T R}-\mathbf{T C} \\
& \pi=\text { Pendapatan } \\
& \text { TR }=\text { Total Revenue } \\
& (\text { Total Penerimaan }) \\
& \text { TC }=\text { Total Cost }(\text { Total Biaya) } \\
& \text { Dimana: TR }=\text { P.Q TC }=\text { FC }+ \text { VC }
\end{aligned}
$$

\section{HASIL DAN PEMBAHASAN}

\section{Deskripsi Tempat Penelitian}

Pasar Tanawangko merupakan salah satu pasar tradisional yang terletak di Desa Borgo Kecamatan Tombariri Kabupaten Minahasa, pasar Tanawangko telah di renovasi dan mulai beroperasi kembali sejak 10 Juni 2020. Pasar Tanawangko ini dibangun diatas lahan pemerintah Kabupaten Minahasa yang diperoleh melalui hibah tanah dari pemerintah Desa Borgo dengan lahan seluas $\pm 3.900 \mathrm{~m} 2$ dengan luas bangunan \pm $1.515,44 \mathrm{~m} 2$. Pasar Tanawangko di pimpin oleh Feibe Mumek serta dibantu oleh wakil Hendra Senewe, untuk semua masalah teknis pasar. Pasar Tanawangko memiliki 76 pedagang yang berasal dari Kecamatan Tombariri.

\section{Umur}

\section{Karakteristik Responden}

Umur yang produktif pada usia 16 tahun sampai 59 tahun, jika diatas 60 tahun maka produktifitas pedagang akan semakin menurun. Menurut penelitian yang sudah dilakukan umur responden dapat dilihat pada Tabel 1.

Tabel 1. Umur Responden Pedagang Pasar

\begin{tabular}{cccc}
\hline No & Umur(tahun) & $\begin{array}{c}\text { Jumlah } \\
\text { Pedagang }\end{array}$ & Presentase (\%) \\
\hline 1 & $16-59$ & 18 & 90 \\
2 & $>60$ & 2 & 10 \\
\hline & Jumlah & $\mathbf{2 0}$ & $\mathbf{1 0 0}$ \\
\hline \multicolumn{2}{l}{ Sumber: Data Primer yang Diolah, 2020 }
\end{tabular}

Tabel 1 diketahui bahwa sebagian besar responden berada pada usia produktif, yaitu umur 16 sampai 64 tahun pada responden.

\section{Tingkat Pendidikan}

Pendidikan sangat penting dalam meningkatkan pendapatan pedagang dan cara berpikir pedagang dalam mengurangi biaya dan mendapatkan keuntungan dengan semaksimal mungkin. Berdasarkan hasil penelitian, tingkat pendidikan pedagang dapat dilihat pada Tabel 2.

\begin{tabular}{lccc}
\multicolumn{4}{c}{ Tabel 2. Tingkat Pendidikan Responden Pedagang } \\
\hline \multirow{2}{*}{ No } & $\begin{array}{c}\text { Tingkat } \\
\text { Pendidikan }\end{array}$ & $\begin{array}{c}\text { Jumlah } \\
\text { Pedagang }\end{array}$ & Persentase (\%) \\
\hline 1 & SD & 1 & 5 \\
2 & SMP & 2 & 10 \\
3 & SMA & 17 & 85 \\
\hline \multicolumn{5}{l}{ Sumber: Data Primer yang Diolah, 2020 }
\end{tabular}


Tabel 2 menunjukkan bahwa tingkat pendidikan pedagang di pasar Tanawangko yaitu yang tertinggi tingkat pendidikan SMA sebesar $85 \%$, sedangkan untuk yang terendah pada tingkat pendidikan SD sebesar 5\%.

\section{Jumlah Tanggungan Keluarga}

Tanggungan keluarga adalah semua anggota keluarga yang merupakan tanggungan rumah tangga yang dimaksud tersebut. Dari hasil penelitian dapat dilihat jumlah anggota keluarga pedagang pada Tabel 3 .

Tabel 3. Jumlah Tanggungan Anggota Keluarga Responden

\begin{tabular}{cccc}
\hline No & Tanggungan & Jumlah Responden & Presentase (\%) \\
\hline 1 & $1-2$ & 12 & 60 \\
2 & $3-4$ & 8 & 40 \\
\hline \multicolumn{5}{l}{ Jumlah } & $\mathbf{2 0}$ & $\mathbf{1 0 0}$
\end{tabular}

Tabel 3 menunjukkan tanggungan anggota keluarga tertinggi yaitu pada tanggungan 1 sampai 2 dengan persentase $60 \%$. Sedangkan untuk 3 sampai 4 dengan persentase $40 \%$ dari total responden.

\section{Produk Dagangan}

Produk dagangan adalah barang yang dibeli oleh pemilik usaha dengan tujuan untuk menghasilkan keuntungan. Selanjutnya pada tabel disajikan produk dagangan pedagang.

\begin{tabular}{|c|c|c|c|}
\hline No & $\begin{array}{c}\text { Produk } \\
\text { Dagangan }\end{array}$ & $\begin{array}{c}\text { Jumlah } \\
\text { Responden }\end{array}$ & $\begin{array}{c}\text { Presentase } \\
(\%)\end{array}$ \\
\hline 1 & Tomat & 15 & 6.91 \\
\hline 2 & Cabai & 15 & 6.91 \\
\hline 3 & Bawang merah & 15 & 6.91 \\
\hline 4 & Bawang Putih & 15 & 6.91 \\
\hline 5 & Caisin & 10 & 4.61 \\
\hline 6 & Wortel & 9 & 4.15 \\
\hline 7 & $\begin{array}{l}\text { Rampah } \\
\text { Rampah } \\
\text { Campur }\end{array}$ & 10 & 4.61 \\
\hline 8 & lemon cui & 15 & 6.91 \\
\hline 9 & Kangkung & 10 & 4.61 \\
\hline 10 & Pisang & 9 & 4.15 \\
\hline 11 & cabe keriting & 15 & 6.91 \\
\hline 12 & Kunyit & 8 & 3.69 \\
\hline 13 & Jahe & 14 & 6.45 \\
\hline 14 & Ketimun & 8 & 3.69 \\
\hline 15 & sayur pakis & 8 & 3.69 \\
\hline 16 & Kentang & 9 & 4.15 \\
\hline 17 & Kol & 8 & 3.69 \\
\hline 18 & bunga kol & 8 & 3.69 \\
\hline 19 & labu siam & 8 & 3.69 \\
\hline 20 & Bayam & 8 & 3.69 \\
\hline & Jumlah & 217 & 100 \\
\hline
\end{tabular}

Sumber: Diolah dari data Primer, 2020
Berdasarkan penelitian di pasar produk paling banyak terjual yaitu tomat, cabai, bawang merah, bawang putih, lemon cui, cabai kriting sebanyak $6.91 \%$, sedangkan yang terendah adalah kunyit, ketimun, sayur pakis, kol, bunga kol, labu siam, dan bayam sebesar 3,69\%.

\section{Retribusi, Pendapatan, Pembelian dan Penjualan}

Retribusi merupakan biaya yang harus dibayarkan oleh pengguna fasilitas kepada pemilik atau pengelola sebagai syarat menggunakan fasilitas tersebut. Penjualan adalah sebuah usaha atau langkah konkrit yang dilakukan untuk memindahkan suatu produk, baik itu berupa barang atau jasa, dari produsen kepada konsumen sebagai sasarannya. Pendapatan merupakan jumlah uang yang didapat atau diterima oleh perusahaan dari suatu aktivitasnya, hampir semua dari penjualan produk ataupun jasa kepada pelanggan.

Tabel 5. Penjualan, Pembelian, Retribusi dan Pendapatan

\begin{tabular}{ccc}
\hline $\begin{array}{c}\text { Total } \\
\text { Penerimaan }\end{array}$ & Total Biaya & Keuntungan \\
\hline Rp 2,909,750 & Rp 2,097,450 & Rp. 812,300 \\
\hline Sumber: Diolah dari data Primer, 2020 &
\end{tabular}

Bedasarkan hasil penelitian, Total Penerimaan Sebesar Rp 2,909,750 sedangkan untuk total biaya sebesar Rp 2,097,450 yang terdiri dari Modal usaha dan biaya retribusi pasar. Untuk keuntungannya sebesar Rp. 812,300 per minggu, untuk kegiatan penjualan yaitu pada hari senin dan kamis selama pandemi covid-19.

\section{KESIMPULAN DAN SARAN}

\section{Kesimpulan}

Berdasarkan hasil penelitian, pedagang Pasar Tanawangko masih memiliki Keuntungan pada masa pandemi dengan rata - rata Rp. 812,300 / Minggu.

\section{Saran}

Saran untuk pedagang Pasar Tanawangko untuk menambah jenis jualan alternatif kebutuhan pada masa pandemi agar meningkatkan pendapatan pedagang. 


\section{DAFTAR PUSTAKA}

Amstrong dan Kotler, 1999. PrinsipPrinsip Pemasaran, Eduisi Delapan, Jakarta: Penerbit Erlangga.

Boediono. 2000. Ekonomi Mikro. Edisi Kedua, Seri Sinopsis Pengantar IlmuEkonomi No. 1. Yogyakarta: Bpfe.

Mubyarto. 1995. Pengantar Ekonomi Pertanian. Jakarta: LP3ES.
Soekartawi. 1995. Analisis Usaha Tani. Universitas Indonesia Press, Jakarta. Gramedia Pustaka Utama, Jakarta.

Stanton, William J. 1993. Prinsip-Prinsip Pemasaran. Jakarta: Erlangga. Sukirno, Sadono, 2006, Ekonomi Pembangunan, Jakarta: Kencana. 